\title{
Patterns of bacterial resistance against Ceftriaxone from 2002 to 2005 in the Clinical Microbiology Laboratory of the Faculty of Medicine, University of Indonesia
}

\author{
Yeva Rosana, Ariyani Kiranasari, Ika Ningsih, Conny Tjampakasari, Retno Kadarsih, Mardiastuti H. Wahid
}

\begin{abstract}
Abstrak
Penyebaran mikroba yang resisten terhadap pengobatan merupakan tantangan kesehatan masyarakat yang menyeluruh, yang akan menurunkan efektivitas obat dan mengakibatkan tingginya angka kesakitan dan kematian serta bertambahnya biaya pengobatan. Pengawasan resistensi obat antimikrobial melalui laporan data tentang pola resistensi mikroba terhadap suatu antimikroba akan berguna untuk mencegah timbulnya resistensi. Pada studi ini akan dilaporkan tentang pola resistensi mikroba terhadap ceftriaxone dalam 4 tahun terakhir. Data yang dilaporkan ini berasal dari spesimen yang diperiksa di Laboratorium Mikrobiologi Klinik, Departemen Mikrobiologi FKUI dari tahun 2002 sampai dengan 2005. Spesies mikroba ditentukan melalui kultur dan uji identifikasi. Disc Diffussion Methods digunakan untuk uji sensitivitas ceftriaxone terhadap 14 bakteri Gram-negatif dan 7 bakteri Gram-positif. Hasilnya memperlihatkan, walaupun angka resistensi mikroba terhadap ceftriaxone meningkat dari tahun 2002 sampai 2005, tetapi secara umum masih kurang dari 50\%. Angka resistensi yang rendah (<3\%) terlihat untuk Salmonella typhi, Salmonella paratyphi A, Shigella flexneri, Serratia marcescens, dan Streptococcus pneumoniae. Hasil ini dapat digunakan untuk menyusun pedoman penggunaan ceftriaxone di Indonesia. (Med J Indones 2007; 16:3-6)
\end{abstract}

\begin{abstract}
The spread of drug resistant microbes is a global public health challenge which impairs the efficacy of antimicrobial agents and causes substantial increase in morbidity and mortality rates, including healthcare-associated costs. Monitoring of antimicrobial drug resistance from documented microbial epidemiology \& resistance rate is useful in preventing the emergence of resistance. This study reports on the pattern of bacterial resistance against ceftriaxone in the past 4 years. The data were obtained from specimens examined in the Clinical Microbiology Laboratory, Department of Microbiology Faculty of Medicine, University of Indonesia from 2002 to 2005. Microbial species were determined from culture and identification tests. Disc diffusion method was used for sensitivity testing of ceftriaxone to 14 Gram-negative and 7 Gram-positive bacteria. Although resistance rates were increased from 2002 to 2005 , resistance rates of ceftriaxone were found to be less than 50\%. Low resistance rates $(<3 \%)$ were observed for Salmonella typhi, Salmonella paratyphi A, Shigella flexneri, Serratia marcescens, and Streptococcus pneumoniae. These results could be useful in developing guidelines on the use of ceftriaxone in Indonesia. (Med J Indones 2007; 16:3-6)
\end{abstract}

Keywords: Microbial drug resistance, disc diffusion method, Gram-positive, Gram-negative

The spread of drug resistant microbes is a global public health challenge, which impairs the efficacy of antimicrobial agents and causes substantial increase in morbidity and mortality rates and also healthcareassociated costs. ${ }^{1-4}$ The impact of this problem is emphasized in low-resource countries because of the high prevalence of bacterial infections and the major

Department of Microbiology, Faculty of Medicine, University of Indonesia, Jakarta, Indonesia role of antimicrobial agents in combating infectious diseases. ${ }^{1,4-6}$

To prevent the emergence of resistance, it is important to monitor antimicrobial drug resistance from periodically documented local microbial epidemiology and resistance rate studies.

Multiple mechanisms have been pronounced in explaining antimicrobial agent resistance. These mechanisms include enzymatic inhibition of drugs, alteration of proteins targeted by antibiotics, changes in metabolic pathways, antibiotic efflux, alterations in porin channels, and changes in membrane permeability. ${ }^{7}$ 
Bacterial resistance to cephalosporins generally arises from the production of $\beta$-lactamases, enzymes that hydrolyze the $\beta$-lactam ring. Resistance can also be achieved by reduced cell wall penetrability and/or altered penicillin binding proteins (PBPs). ${ }^{8}$

The objective of this study is to report patterns of bacterial resistance against ceftriaxone in the past 4 years (2002 to 2005) from our laboratory that will be useful in for further evaluation on the wide range of ceftriaxone use (including respiratory tract infections, uncomplicated urinary tract infection, bacterial meningitis in children, bone, skin and soft tissue infections, bacterial septicemia, intra-abdominal infections, acute bacterial otitis media and for surgical prophylaxis). ${ }^{9}$

\section{METHODS}

Data were collected from specimens examined in the Clinical Microbiology Laboratory, Department of Microbiology, Faculty of Medicine University of Indonesia from 2002 to 2005.

Data collected were microbial species and ceftriaxone resistance profile. Microbial species were determined from culture and identification tests. The isolated species were screened for anti-microbial resistance profile using the disc diffusion method according to the methods recommended by the National Committee for Clinical Laboratory Standards Guidelines (NCCLS). ${ }^{10-12}$

Sensitivity data were recorded quantitatively by measuring the diameters to the nearest whole millimeter. Following the interpretative chat of the Kirby-Bauer Sensitivity Test Method, the zones were interpreted as resistant, intermediate or sensitive.

The species grew from each specimens and ceftriaxon resistance profile of each specimens were noted. The data were tabulated according to the species, number of specimens and resistance rate per year.

\section{RESULTS}

There were 14 Gram negative and 7 Gram positive bacteria collected from specimens used for sensitivity testing to ceftriaxone.

From year 2002 to 2005, resistance rates of ceftriaxone to the 14 Gram negative and 7 Gram positive bacteria tested were increased, but less than 50\%. Highest resistance rate were observed for Acinetobacter anitratus, Pseudomonas aeruginosa, and Streptococcus viridans, alpha-haemolytic. Low resistance rates $(<3 \%)$ were observed for Salmonella typhi, Salmonella paratyphi A, Shigella flexneri, Serratia marcescens, and Streptococcus pneumoniae (Table 1 and 2).

Table 1. Microbial resistance patterns of ceftriaxone to Gram-negative bacteria in the past 4 years

\begin{tabular}{lcccccccc}
\hline & \multicolumn{2}{c}{2002} & \multicolumn{2}{c}{2003} & \multicolumn{2}{c}{2004} & \multicolumn{2}{c}{2005} \\
\cline { 2 - 9 } Gram-negative bacteria & $\mathrm{n}$ & $\mathrm{R}(\%)$ & $\mathrm{n}$ & $\mathrm{R}(\%)$ & $\mathrm{n}$ & $\mathrm{R}(\%)$ & $\mathrm{n}$ & $\mathrm{R}(\%)$ \\
\hline Acinetobacter anitratus & 68 & 19.1 & 45 & 26.7 & 160 & 43.1 & 173 & 47.4 \\
Alcaligenes faecalis & 47 & 17.0 & 34 & 26.5 & 53 & 20.8 & 68 & 26.5 \\
Enterobacter aerogenes & 86 & 27.9 & 103 & 26.2 & 145 & 31.7 & 117 & 25.6 \\
Escherichia coli & 157 & 17.8 & 139 & 23.7 & 273 & 22.3 & 253 & 26.1 \\
Klebsiella pneumoniae ss. pneumonia & 198 & 28.8 & 218 & 25.7 & 448 & 30.6 & 271 & 32.8 \\
M. (bran) Catarrhalis & 38 & 0 & 21 & 0 & 13 & 15.4 & 5 & 0 \\
Pseudomonas aeruginosa & 207 & 35.3 & 200 & 41 & 336 & 42 & 233 & 45.5 \\
Proteus mirabilis & 50 & 2.0 & 44 & 6.8 & 108 & 3.7 & 77 & 10.4 \\
Proteus vulgaris & 5 & 20.0 & 5 & 20 & 8 & 12.5 & 6 & 16.7 \\
Salmonella typhi & 2 & 0 & 2 & 0 & 9 & 0 & 7 & 0 \\
Salmonella paratyphi A & 1 & 0 & 1 & 0 & 1 & 0 & 2 & 0 \\
Shigella flexneri & 1 & 0 & - & - & - & - & - & - \\
Serratia marcescens & 2 & 0 & 1 & 0 & 3 & 0 & - & - \\
Y. pseudotuberculosis & 5 & 0 & 1 & 0 & 4 & 50 & 2 & 0 \\
\hline
\end{tabular}


Table 2. Microbial resistance patterns of ceftriaxone to Gram-positive bacteria in the past 4 years

\begin{tabular}{lcccccccc}
\hline & \multicolumn{2}{c}{2002} & \multicolumn{2}{c}{2003} & \multicolumn{2}{c}{2004} & \multicolumn{2}{c}{2005} \\
\cline { 2 - 9 } Gram-positive bacteria & $\mathrm{n}$ & $\mathrm{R}(\%)$ & $\mathrm{n}$ & $\mathrm{R}(\%)$ & $\mathrm{n}$ & $\mathrm{R}(\%)$ & $\mathrm{n}$ & $\mathrm{R}(\%)$ \\
\hline Staphylococcus aureus & 142 & 14.8 & 148 & 16.8 & 276 & 15.9 & 232 & 18.1 \\
Staphylococcus albus & 155 & 11.6 & 137 & 21.2 & 303 & 20.5 & 179 & 22.3 \\
Streptococcus anhaemolyticus & 37 & 21.6 & 33 & 48.5 & 69 & 30.4 & 57 & 29.8 \\
Streptococcus betahaemolyticus & 26 & 11.5 & 39 & 5.1 & 13 & 0 & 12 & 16.7 \\
Streptococcus pneumoniae & 20 & 0 & 19 & 0 & 37 & 2.7 & 31 & 0 \\
Streptococcus pyogenes & 3 & 0 & - & - & 2 & 50 & 3 & 33.3 \\
Streptococcus viridans, alpha-haemolytic & 81 & 46.9 & 40 & 42.2 & 114 & 45.6 & 79 & 44.3 \\
\hline
\end{tabular}

\section{DISCUSSION}

There are some limitation that must be considered in the interpreting of our findings, among others, our study derived from data during the period of 2002-2005 in a Microbiology Laboratory and we have no data on duration and result of the ceftriaxone treatment.

Infection is one of the main problems in Indonesia, and the world in general, and is associated with significant morbidity and mortality. Infections caused by bacteria should be treated by antibiotics, also known as antimicrobial drugs. ${ }^{13}$

Obviously, if a bacterial pathogen is able to develop or acquire resistance to an antibiotic, then the antibiotic becomes useless in the treatment of infectious disease. So as pathogens develop resistance, new (different) antibiotics must be discovered to replace the useless ones in the treatment regimens. The problem is not only in finding new antibiotics to fight old diseases (because resistant strains of bacteria have emerged), but also in finding new antibiotics to fight new diseases.

As a consequence of these problems, smart use of antibiotics is the key to control the emergence of resistance. Therefore guidelines for wise antibiotics usage should be available. Monitoring of antimicrobial drug resistance using by reported data on the patterns of bacterial resistance against antimicrobial drugs is useful in preventing the emergence of resistance.

Ceftriaxone is a broad-spectrum cephalosporin, with prolonged pharmacokinetics enabling once daily dosing for intravenous or intramuscular administration. Launched in 1982, this agent has proved highly successful for the treatment of a wide range of indications, including respiratory tract infections, uncomplicated urinary tract infection, bacterial meningitis in children, Lyme disease, bone, skin and soft tissue infections, bacterial septicemia, intra-abdominal infections, acute bacterial otitis media and for surgical prophylaxis. Ceftriaxone is also indicated as single dose treatment of gonorrhoea and chancroid. ${ }^{9}$

Sensitivity testing data from the Clinical Microbiology Laboratory of the Department of Microbiology, Faculty of Medicine University of Indonesia, Jakarta in the past 4 years (2002 to 2005) showed that although resistance rates of ceftriaxone to 14 Gramnegative and 7 Gram-positive bacteria tested were increased, it was less than 50\%. Lower resistance rates $(<3 \%)$ were observed for Salmonella typhi, Salmonella paratyphi A, Shigella flexneri, Serratia marcescens, and Streptococcus pneumoniae.

Despite widespread clinical use since 1985 , a recent survey by the surveillance network (TSN) database in the USA reported that Ceftriaxone retained its potent activity against the most commonly encountered Gram-positive and Gram-negative human pathogens in clinical isolates collected between 1996 and 2000. Specifically, ceftriaxone resistance was low and stable within the range given throughout the four years. ${ }^{14}$

Investigation on the prevalence of fecal carriage of antimicrobial drug-resistant Escherichia coli in 3,174 healthy children from 4 urban settings in Peru and Bolivia reported that the resistance rate to ceftriaxone was uncommon $(<0.5 \%){ }^{1}$

Ceftriaxone was also demonstrated to have a modest degree (60 to 80 percent) of clinical efficacy in the treatment of acute otitis media caused by penicillinresistant S. pneumoniae. ${ }^{15}$ The centers for disease control and prevention (CDC) reports from the drugresistant $S$. pneumoniae therapeutic working group have documented that intramuscular ceftriaxone was efficacious in acute otitis media treatment failures with three daily doses of high-dose amoxicillin; highdose amoxicillin-clavulanate; or cefuroxime axetil. ${ }^{15}$ 
Our report showed similar findings with previous reports, i.e. ceftriaxone was still highly successful for the treatment of a wide range of indications, although resistance rates were increased from 2002 to 2005. To control the spread of ceftriaxone resistance, it is important to evaluate and develop guidelines on ceftriaxone usage in Indonesia.

In conclusion, smart use of antibiotics is the key to control the spread of resistance. To prevent emergence of Ceftriaxone resistance in the future, data about microbial resistance pattern of Ceftriaxone from 2002 to 2005 is important and should be used to develop guidelines or ceftriaxone usage.

\section{Acknowledgement}

The authors wish to thank the Microbiology team of the Faculty of Medicine, University of Indonesia for their technical assistance and cooperation.

\section{REFERENCES}

1. Bartoloni A. Multidrug-resistant Commensal Escherichia coli in Children, Peru and Bolivia. Emerg Infect Dis. 2006: 12: [serial on the Internet]. Available from http://www.cdc.gov/ncidod/EID/vol12no06/05-1258.htm

2. Byarugaba DK. A view on antimicrobial resistance in developing countries and responsible risk factors. Int $\mathbf{J}$ Antimicrob Agents. 2004;24:105-10.

3. World Health Organization. WHO report on infectious diseases 2000. Overcoming antimicrobial resistance. Geneva: The Organization; 2000.

4. World Health Organization. Global strategy for containment of antimicrobial resistance. Geneva: The Organization;
2001 [cited 2006 Jan 27]. Available from http://www.cdc.gov/ncidod/EID/vol12no06/disc11.htm

5. Okeke IN, Lamikanra A, Edelman R. Socio-economic and behavioral factors leading to acquired bacterial resistance to antimicrobrial agents in developing countries. Emerg Infect Dis. 1999;5:18-27.

6. Bartoloni A, Bartalesi F, Mantella A, Dell'Amico E, Roselli M, Strohmeyer M, et al. High prevalence of acquired antimicrobial resistance unrelated to heavy antimicrobial consumption. J Infect Dis. 2004;189:1291-4.

7. Karam GH. Emerging Issues in Antibiotic Resistance in Blood-borne Infections. Am J Respir Crit Care Med. 2000; 162:1610-6.

8. Bijie H. In vitro activity, pharmacokinetics, clinical efficacy, safety and pharmacoeconomics of ceftriaxone compared with third and fourth generation cephalosporins: review. J Chemother. 2005;17: 3-24.

9. Lambert PA. Pharmaceutical quality of ceftriaxone generic drug products compared with Rochephin ${ }^{\circledR}$. J Chemother. 2003;15:357-68.

10. Cappuccino JG, Sherman N. Microbiology, a Laboratory Manual. $7^{\text {th }}$ edition. San Fransisco: Pearson, Benjamin Cummings; 2005.

11. Norrel SA, Messley KE. Microbiology Laboratory Manual, Principles and Applications. New Jersey: Prentice Hall; 1997.

12. Ferraro MJ, Craig WA, Dudley MN, Eliopeulos G, Hecht $\mathrm{DW}$, et al. Performance standards for antimicrobial susceptibility testing. NCCLS. 2002;22 (12 ${ }^{\text {th }}$ Informational Supplement):17-80.

13. Todar K. Bacterial resistance to antibiotics. Todar's Online Textbook of Bacteriology. 2002. http://www.textbookofbacteriology.net

14. Esposito S. Ceftriaxone prophylaxis in abdominal, cardiovascular, thoracic, orthopaedic, neurosurgical and general surgery: a review of practice 1996-2003. J Chemother. 2005;17 (supl.2):17-32.

15. Pichichero ME. Acute Otitis Media: Part II. Treatment in an era of increasing antibiotic resistance. Am Fam Physician .2000;61:2410-6. 